\title{
A Systematic Approach for Improving the Software Management Process*
}

\author{
Semra Birgün ${ }^{\dagger}$ \\ Faculty of Engineeering and Architecture, Fenerbahçe University \\ 34724 Kad1köy, İstanbul, Turkey \\ semra.birgun@fbu.edu.tr \\ Burcu Tanrikut Çerkezoğlu \\ Halk Hayat ve Emeklilik, 34382 Şişli, İstanbul, Turkey \\ burcutanrikut@hotmail.com
}

Received 23 October 2017

Revised 13 October 2018

Accepted 14 October 2018

Published 23 November 2018

\begin{abstract}
Information technology is an indispensable element in applications in today's industrial era. In addition to modern management approaches, software just as well as hardware is of great importance to ensure competitive advantage if the company needs to keep pace with industrial requirements. Information sector can be seen as a competition opportunity for emerging countries. To be able to exploit this opportunity, companies need to be agile and innovative. In this paper, we suggest a process innovation which is intended to be a new model for designing an efficient and effective software process. The model was applied at a software company, and the results of this study are reported here. Lean and agile approaches were used, and as a result, the firm achieved significant improvements in cost, time, labor force, quality, internal and external customer satisfaction, speed, reliability and productivity.
\end{abstract}

Keywords: Software development; lean; agile.

\section{Introduction}

The information technology that created the third industrial revolution in the 1970s has become an indispensable element of all companies today whether they are in services or in manufacturing. Many of the new industrial applications called "revolutionary" could not have been possible without IT. In today's technology, which evolves and is called Industry 4.0, companies need to have the resources and methods to be able to innovate themselves and comply with Industry 4.0 in order

*This paper is based on the master's thesis of the second author, presented to the Institute of Natural and Applied Sciences of Beykent University, Istanbul, Turkey, under the title of "Improvement of the Project Management Process: An Application in Software Industry".

$\dagger$ Corresponding author. 
to grow, compete or at least sustain their presence in the global marketplace. Managers must implement these strategies according to the new industrial era and they must fulfill these strategies successfully. In addition to other management factors, the right selection, correct and effective implementation of IT technologies that they use to manage their resources and the correct interpretation of results are the most important factors affecting success. Companies need most of the time and effort to develop most software in-house. Developing software in-house is costly, and improving the management of software development may result in considerable savings and improved quality, and thus yield a competitive advantage.

Clearly, software companies and programmers play a large role in the competitiveness of companies. In order to support their customers as well as outpace their competitors, software companies have to adapt to the new era of industry. The software industry is crucial for both developed and emerging markets. To operate in compliance with Industry 4.0, an industry with a high level of R\&D work and high technology is needed. The provision of such an environment is even more challenging for the manufacturing sectors of developing countries. However, the software industry can be seen as an opportunity for emerging markets. The software industry may offer emerging markets the chance to close the gap with developed countries in many fields. In this era of speed, quality and agility, software companies need to ensure their processes are well defined, improve on them, and adapt to the age of Industry 4.0 in order to maximize customer satisfaction.

In this paper, a model is developed using lean and agile approaches to improve the software development process (SDP). The improvement of a software project operating according to the classical waterfall model and facing problems is handled through a case study. With this model application, an innovative process is designed according to the needs of the age and the results obtained with the applied design steps are presented. These systematic steps are intended to serve as guidelines for innovative management of software development.

\section{An Overview of Software Project Management}

Software project management is the entirety of activities carried out to customer requirements within specified time and cost limits. These activities include planning, managing, coordinating, informing, controlling, and making the necessary corrections and improvements for solving the problems [Svensson (2006); Kaur and Sengupta (2013)]. Teamwork is imperative for large-scale projects. Project management is the activity of carrying out team activities within the scope of the purpose, communicating within the team, directing the team and evaluating the appropriateness of the work done.

Today, many software projects are not completed successfully. Standish Group which conducted studies in the field of IT regularly classifies the IT projects as successful, challenged, and failed, in the "Chaos" reports published every year [Hastie (2015); Standish Group (2016)]. The rates of software projects by the year specified are presented in Table 1. 
Table 1. The successful rates of software projects, 1994-2015.

\begin{tabular}{lccccccccccccc}
\hline & 1994 & 1996 & 1998 & 2000 & 2002 & 2004 & 2006 & 2009 & 2011 & 2012 & 2013 & 2014 & 2015 \\
\hline Successful & $16 \%$ & $27 \%$ & $26 \%$ & $28 \%$ & $34 \%$ & $29 \%$ & $35 \%$ & $32 \%$ & $37 \%$ & $27 \%$ & $31 \%$ & $28 \%$ & $29 \%$ \\
Challenged & $53 \%$ & $33 \%$ & $46 \%$ & $49 \%$ & $51 \%$ & $53 \%$ & $46 \%$ & $44 \%$ & $42 \%$ & $56 \%$ & $50 \%$ & $55 \%$ & $52 \%$ \\
Failed & $31 \%$ & $40 \%$ & $28 \%$ & $23 \%$ & $15 \%$ & $18 \%$ & $19 \%$ & $24 \%$ & $21 \%$ & $17 \%$ & $19 \%$ & $17 \%$ & $19 \%$ \\
\hline
\end{tabular}

Source: Hastie [2015].

Failure in software projects leads to large losses. According to research by the Standish Group [2015]. 31.1\% of projects are canceled before completion. Besides this, lost opportunity costs should be taken into account. In the same report, the factors leading to failure and their rate of occurrence are also given, and these are reported in Table 2 .

Accordingly, Hastie [2015] cited several reasons that led to the failure of software projects. These include the failure of project managers to understand user requirements, incomplete or incorrect identification of requests and needs, improper management of project changes, unrealistic project delivery dates, change of selected technology, user dissatisfaction, failure to create the right project team and project management team's disregard of previously acquired experience.

In their study, Neumann et al. [2003] emphasized that one of the most common problems of IT projects is on time and on budget completion. Software projects often encounter problems such as lagging behind, over budgeting, poor quality, lack of continuity and reliability, and inadequacy of user claims.

In the course of most traditional software projects, user wishes are obtained at the beginning of the project, the firm contacts the user at various stages of the project but does not include the user in the production process of the software. It will address any complaints after the project's completion. For this reason, mistakes arising from wrong or incomplete understanding of requests cause problems in a very intense way. Yet these initial errors are carried through to all phases of the project, such as design, coding, transition to implementation. In addition to the software produced; dissatisfied customers, lost time and effort, opportunity losses on the user side, unplanned costs on the manufacturer side and various waste are the outputs of

Table 2. Project impairment factors and their rates.

\begin{tabular}{lr}
\hline 1. Incomplete requirements & $13.1 \%$ \\
2. Lack of user involvement & $12.4 \%$ \\
3. Lack of resources & $10.6 \%$ \\
4. Unrealistic expectations & $9.9 \%$ \\
5. Lack of executive support & $9.3 \%$ \\
6. Changing requirements and specifications & $8.7 \%$ \\
7. Lack of planning & $8.1 \%$ \\
8. Did not need it any longer & $7.5 \%$ \\
9. Lack of IT management & $6.2 \%$ \\
10. Technology illiteracy & $4.3 \%$ \\
Others & $9.9 \%$ \\
\hline
\end{tabular}

Source: Hastie [2015]. 
system. When considering today's Industry 4.0 applications [Birgün and Çerkezoğlu (2017); Hermann et al. (2015); TUSIAD (2016)], such as systems communication, security of information, etc., it is obvious that these glitches and delays in the software process will lead to huge losses in the national/global environment. In order to prevent these negative consequences and achieve success, the right processes must be designed and the processes must be operated correctly and effectively. In order for software projects to be successful, best practices and systems should be implemented within the organization and projects should be managed in accordance with the current competitive system of Industry 4.0.

\section{Software Development Process and Sample Studies}

SDP is a process consisting of planning, analysis, design, coding, testing, commissioning and maintenance phases. Although the processes are different, there are activities that are common to all software processes [Nizam (2015)]. These are as follows:

- Identification of software features: Identification of software requirements and constraints.

- Software design and implementation.

- Provision and delivery of the validity of the software: Testing to make sure that customer needs are met and delivery.

- Software maintenance: Maintenance of the software against changes in customer needs or against any mistakes that occur.

The conversion of needs into software occurs stage by stage as shown in Fig. 1. First, the general framework of the software is drawn and a general plan is prepared. Then the needs are analyzed in detail and how this analysis is implemented with software tools is designed. Display, report, object and database structures are created with code. The project is tested to see if it meets the requirements and if there is an error in the software. Once the defects detected in the testing stage are resolved, the project proceeds to the training and installation stage. After the project is turned on for customer use, maintenance and support work continues in order to detect overlooked faults and to meet new user requests. Briefly, the SDP in engineering is planning, standardized in requirements analysis, design, implementation, testing, deployment and maintenance.

Different paths to be followed while pursuing the goal of meeting the need for software are standardized as software process models. The process model specifies the order of stages and the transition criteria between them. A process model is useful because it helps to remind the necessary steps of the plan and to prevent

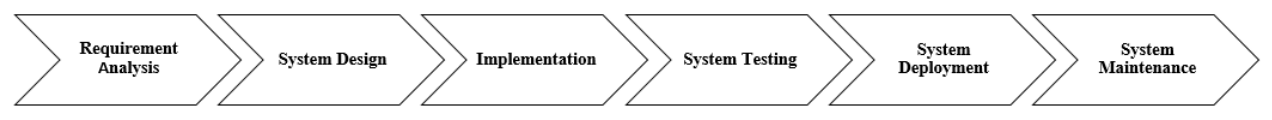

Fig. 1. Software development cycle. 
important processes from being bypassed. Examples of such models are given below [Nizam (2015)]:

(1) Code-driven Models (Code and Edit)

(2) Linear Models

(i) Waterfall Model

(ii) V Model

(3) Evolutionary Process Models

(i) Incremental Model

(ii) Spiral Model

(iii) RUP - Rational Unified Process

(4) Agile Methodologies [Boehm and Turner (2003); Hastie (2015)]

(i) Feature Driven Development (FDD) [Palmer and Felsing (2001)]

(ii) XP (Extreme Programming) [Acar (2008)]

(iii) SCRUM [Deemer et al. (2012); Sutherland and Schwaber (2016)].

The first writing-specific process model has been the CMM, a Capability Maturity Model developed at the Institute of Software Engineering at Carnegie Mellon University, founded by the US Department of Defense. In 1995 the first version was published as the ISO 15504 technical report. In 1998, the third version was published as an official ISO software process assessment standard [ISO/IEC (2006)].

Abe et al. [2006] have proposed statistical methods in software methodologies to objectively base their process improvement efforts and provide control. The software project focuses on the identification of software characteristics in order to capture more success in the research on project output.

Gül [2006] examined the SDP in terms of its fundamentals. Software development methods, basic activities in SDP, project management processes, improvement and modeling of SDP, reasons of project failure, success factors are explained on application. Gül [2006] created a questionnaire on SDPs for the firms that produce software in Turkey and evaluated the findings obtained from this questionnaire. Gül [2006] pointed out that "management support" and "the necessity of taking up improvement efforts as projects in themselves" are important.

Çandur [2010] has worked on the establishment of the IT infrastructure system in the banking sector. Planning of project and project team, planning of IT infrastructure system, project failures and solution proposal, department and task descriptions, banking IT project planning and management are discussed. Using MS Project software, the system is planned. Çandur has made improvements in the project management and has argued that MS Project contributes to implementation methods in banking project management.

Nalbant [2012] proposes an information system that enables automation of the SDP for use by software companies. This automation system enables software projects to be planned, managed, controlled, measured and improved. Nalbant advocates that this system can make SDPs more productive; and presents a model. 
Başar et al. [2014] have made a transition from Waterfall method to Agile method in a technology company. The agile method adopted was SCRUM. SCRUM was applied for five years in all software development stages of the company. However, in the course of time, the use of this method encountered various problems and therefore Kanban was adopted. In the adaptation of the Kanban method to the firm, the experience gained from using the SCRUM method has been used. It was determined that the first results obtained with the method of Kanban show the increase in quality and it is suggested that the use of this method will be more beneficial for the firm.

Çetin and Durdu [2015] have made a study to determine the current situation, including the use and promised advantages of the Agile software development methods. Collecting data from 74 companies, they examined the prevalence of the use of agile versus traditional approaches in the software sector in Turkey. According to the survey results, it is observed that the rates are close to each other and increasingly tend to agile approaches. Software developers have stated that agile approaches increase productivity, quality and customer satisfaction.

Güven [2015] focuses on the importance of lean methodology in the IT industry. He argued that the failures in the projects stem from the system, not management. He has resources, can be achieved with lean methodologies in the firm.

There are numerous studies in software project development area. The studies summarized briefly above are just a few of the studies focusing on process improvement, and lean and agile applications in software development. In the following section, a systematic approach has been proposed in which lean and agile approaches for software development are applied together and support Industry 4.0.

\section{A Systematic Approach for Improving the Software Development Process}

In this section, the steps to redesign a real process in order to recover problems and eliminate waste are explained systematically and then the steps are presented as a model. The study was done at SBT Company. This study has been done for the decision of SBT management to improve the quality and efficiency of their processes which is constantly encountered with the problems to be explained in detail below.

SBT Company is a medium-sized company that develops software and offers consulting services to the software industry in Turkey. The company produces services in Software Development, Business and System Analysis, Test Engineering, Project Management, Operation Support, Enterprise Architecture, Version and Configuration Management and System Integration. Offering comprehensive software solutions with a customer-focused service approach, SBT develops turn-key projects by creating a joint project team with its customers. In addition to readymade products such as Workflow and Document Management, the company produces software solutions that customers need for turn-key projects. It also undertakes large-scale software projects in the field of insurance sector software, telecommunication and e-commerce software and provides services for twelve companies in insurance, telecommunication and e-service. 
About 150 white-collar employees who produce software as individuals or in teams are employed in the firm. Employees with at least 2 years of experience in desired fields in line with the wishes of the companies are employed on an annual or monthly contract.

There are some problems because information projects are expensive, time consuming and laborious. The firm management investigated the main problems of the company by using the nominal group technique [Aktan (2008)] and determined that the administrative problems listed below were causing problems in the projects and causing late deliveries or undeliverable operations:

- employee inadequacy,

- failure to establish appropriate team for the project,

- customer pressure for delivery of the products before the due date,

- customer's constantly changing requests,

- failure to accurately analyze customer requests and avoid communication with customers,

- failure to create necessary budget and resources,

- incorrect technology and architectural choice,

- failure to implement project management methods.

Management decided to improve the software process with the aim of eliminating these problems and ensuring the sustainability of the company. For this purpose, a process project team was established and with a pilot project the results of the process improvement steps were evaluated. Innovations were made in the process by using Group Technology, Lean and Agile techniques for process analysis and redesign. In the following sections, these steps and the methods used are explained in order.

\subsection{Establishing the software project team}

The software firm established the project team. Frequent changes due to customer's changing demands are common in software management. Unless the team is put together taking into account this flux nature of software development, where the product is "active", with the customer continuously putting in new input or asking for modifications, the project may soon spiral into a vicious cycle of unfinished analysis and planning processes. That is the biggest obstacle to achieving the goal. Therefore, all of the activities that need to be staffed are included in the project plan. Project stakeholders and organizational structure are given in Fig. 2.

Activities such as program installation, documentation and user trainings, which are mandatory for the system infrastructure related to software development, are specified in the plan. Vacation and leave periods are also added to the plan. Otherwise, it will lead to disruption in the project duration. User requests were chosen as the product family. Each request is evaluated under the name of software project. Software projects consist of Budgeting, Budget Approval and Sponsor Assignment, Requirement Analysis Preparation, Designing, Coding, Testing, User Testing, User Approval and Deployment phases. Table 3 describes these tasks and details. 


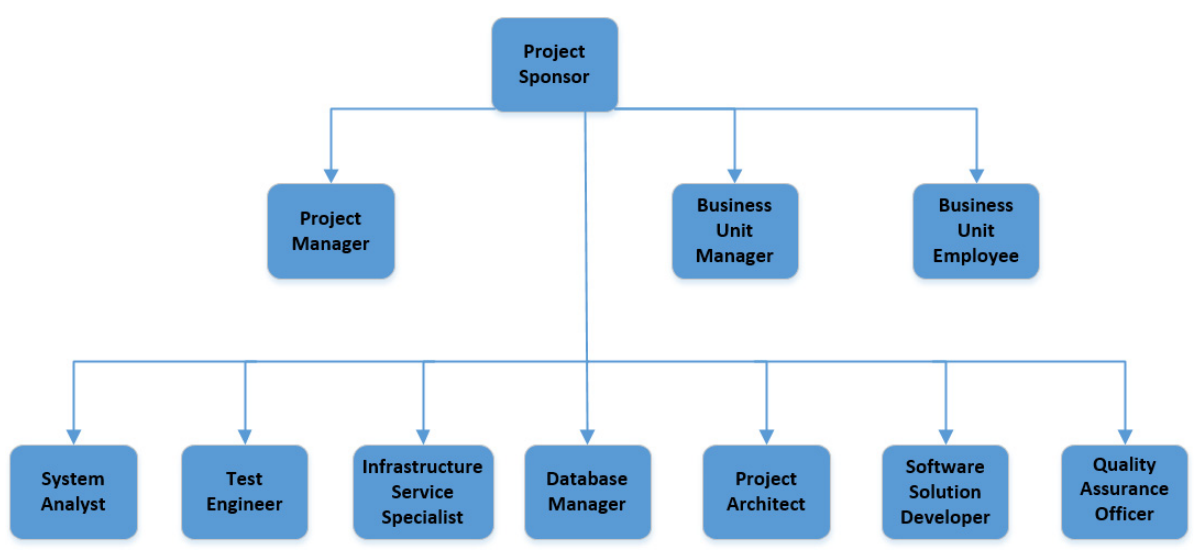

Fig. 2. Project organization chart.

Table 3. Tasks and details in the software project.

\begin{tabular}{|c|c|}
\hline Task name & Task detail \\
\hline Budgeting & $\begin{array}{l}\text { Similarity to previous projects } \\
\text { Preparing a budget report }\end{array}$ \\
\hline Receive Budget Approval and Assign Sponsor & $\begin{array}{l}\text { Review and approve the budget report } \\
\text { Assigning a sponsor }\end{array}$ \\
\hline Preparation of Requirement Analysis & $\begin{array}{l}\text { Detail of requirements } \\
\text { Preparation of business requirements document } \\
\text { Preparation of the requirements analysis document } \\
\text { Requirement tracking matrix preparation } \\
\text { Similarity to previous projects } \\
\text { Analysis of systems integration }\end{array}$ \\
\hline Design & $\begin{array}{l}\text { User system design } \\
\text { Design of similarities to previous projects } \\
\text { Preparation of architectural contract document } \\
\text { Preparation of physical infrastructure design document } \\
\text { Business analysis and design oversight }\end{array}$ \\
\hline Coding & $\begin{array}{l}\text { Infrastructure works hardware design } \\
\text { Construction of installations } \\
\text { Code development } \\
\text { Screen development } \\
\text { Providing data } \\
\text { Web Service development } \\
\text { Safety tests } \\
\text { Unit tests and unit integration tests }\end{array}$ \\
\hline Testing & $\begin{array}{l}\text { Preparation of test plan } \\
\text { Preparing test scripts } \\
\text { Preparing a version plan and a commissioning plan } \\
\text { Preparation of product description documents } \\
\text { Test preparation and visual inspection } \\
\text { Preparation of test report } \\
\text { Preparation of the acceptance test report }\end{array}$ \\
\hline User Testing & User acceptance tests \\
\hline User Confirmation & End-user approval of the project \\
\hline Deployment & $\begin{array}{l}\text { Preparation of user manual } \\
\text { Prepare version verification criteria and return plan } \\
\text { Productive readiness }\end{array}$ \\
\hline
\end{tabular}


Within 1 day of the completion of the product, all the steps are taken by the programmers to the PROD (production environment is a real-time setting where programs are run and hardware setups are installed and relied on for organization or commercial daily operations) environment from the User Acceptance Testing (UAT is the last phase of the software testing process) environment and the deployment is completed. Errors encountered after taking over the circuit are solved within the day and improvements are made in the form of emergency exits.

During the beginning and end of the project, the flow is as shown in Fig. 3.

\subsection{Current state analysis}

In this step, Value Stream Mapping (VSM) [Rother and Shook (1999); Tapping et al. (2002); Womack and Jones (2003); Birgün et al. (2006a,b); Seth and Gupta

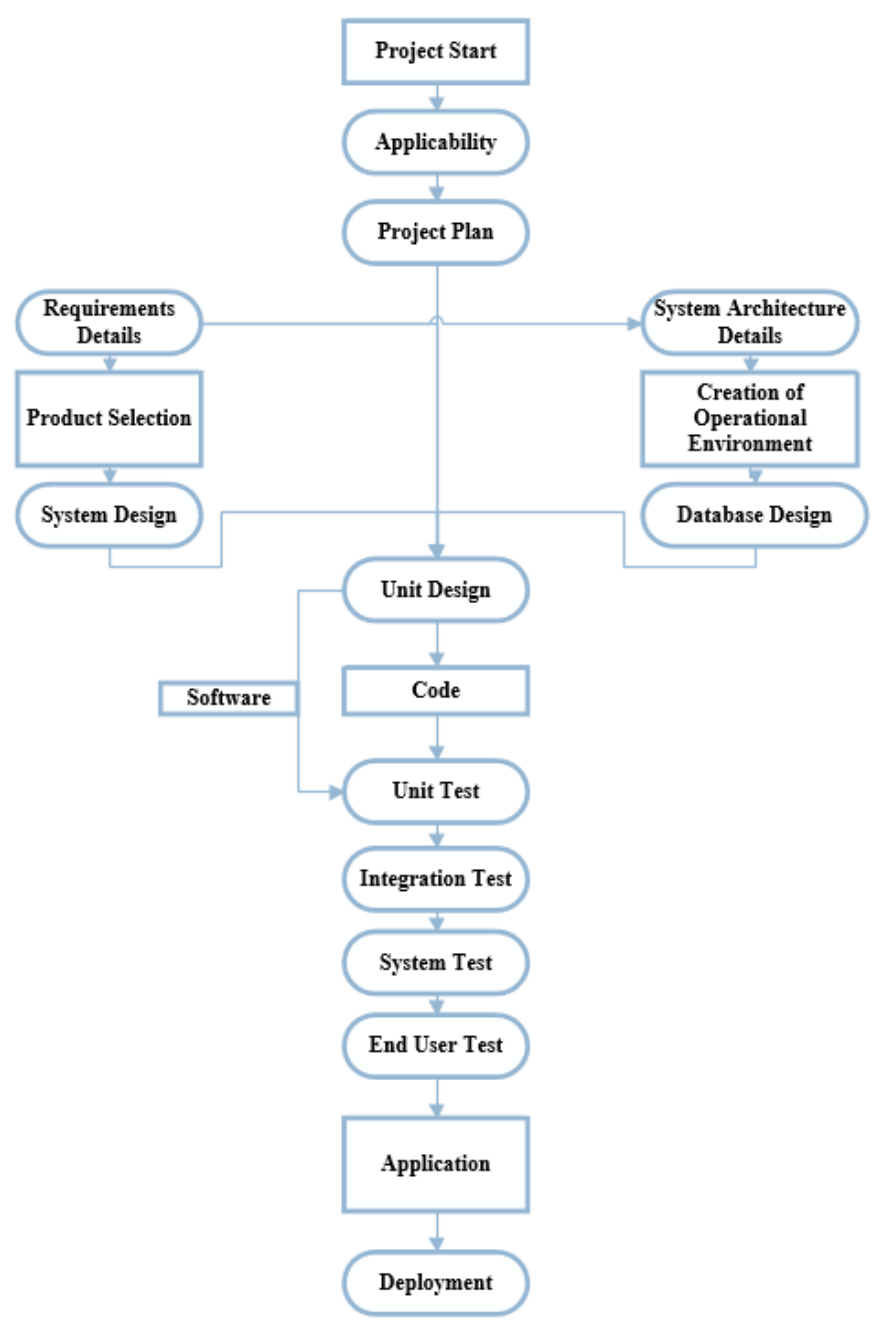

Fig. 3. Project flow chart. 
(2005); Keyte and Locher (2016)], one of the lean techniques, is used to analyze the current situation.

A value stream is all of the activities undertaken in production of a product including both value-added and non-value-added activities. VSM is a map that outlines the current and future state of a production system, allowing users to understand where they are and what wasteful acts need to be eliminated. VSM is executed in four steps such as selecting a product family, drawing the current-state, creating the future-state and the work plan [Rother and Shook (1999); Womack and Jones (2003); Birgün et al. (2006a,b)] VSM is primarily used by Toyota Production System practitioners to depict current and future, or "ideal", states in the process of developing implementation plans to install lean systems.

The company classified the products into three groups: "large-scale project groups" for 3-9 months where projects are produced for e-invoicing, transition to ERP modules, etc., for corporate companies; "Medium-sized project groups" for 1-3 months, in which projects such as screen software, reporting, mobile applications for corporate companies are produced; and "Small scale project groups" for 0-1 month in which projects are produced such as web sites, SMS, etc.

The time-to-value map of the current situation was based on the size of the requests. Users reported their requests and needs to the IT department on a monthly basis. If the duration of incoming requests was long, the request was divided into sub-sections and presented to the user as monthly software versions. Then the demands were processed and budget studies were initiated.

In the current state map, when performing value stream analysis; the user was consulted during the stages of preparing and designing requirements analysis. There were nine stages in the process, and these processes were carried out as in the waterfall model. The company had a single shift system. In Fig. 4, the current state map that was prepared by the authors of this paper may be seen, where the process was followed from the beginning to the end.

According to the current state map, there were waiting periods/non-value added time between 15.5 and 29 days in total. Budget planning reports, which were not prepared in detail in previous projects, caused accumulation of projects and waiting periods. Since no proxy authorizer was indicated for budget approval, the unavailability of the authorized resulted in long wait periods.

Demands were lining up for $3-5$ days according to their size before they arrived at the Budgeting stage. Customer demands, applicability, hardware competencies, time and cost issues were evaluated in detail, and all the issues were clarified before the contract was prepared. At this stage, unevaluated or overlooked entities caused waste such as unnecessary costs, time lost, and even the cancellation of the project. During the budgeting phase, the way and methods to be followed from the beginning to the completion of the project, the cost of the equipment, the work department, the project manager's forecasting and selection, and the distribution of the project steps to the process were evaluated. Priority requests were taken to the budgeting phase, and budget research was done based on former projects. The stage was usually completed within 1-3 days, and there was a half day preparation process. However, in this instance, the process took one day with preparation. Some of the reasons for 


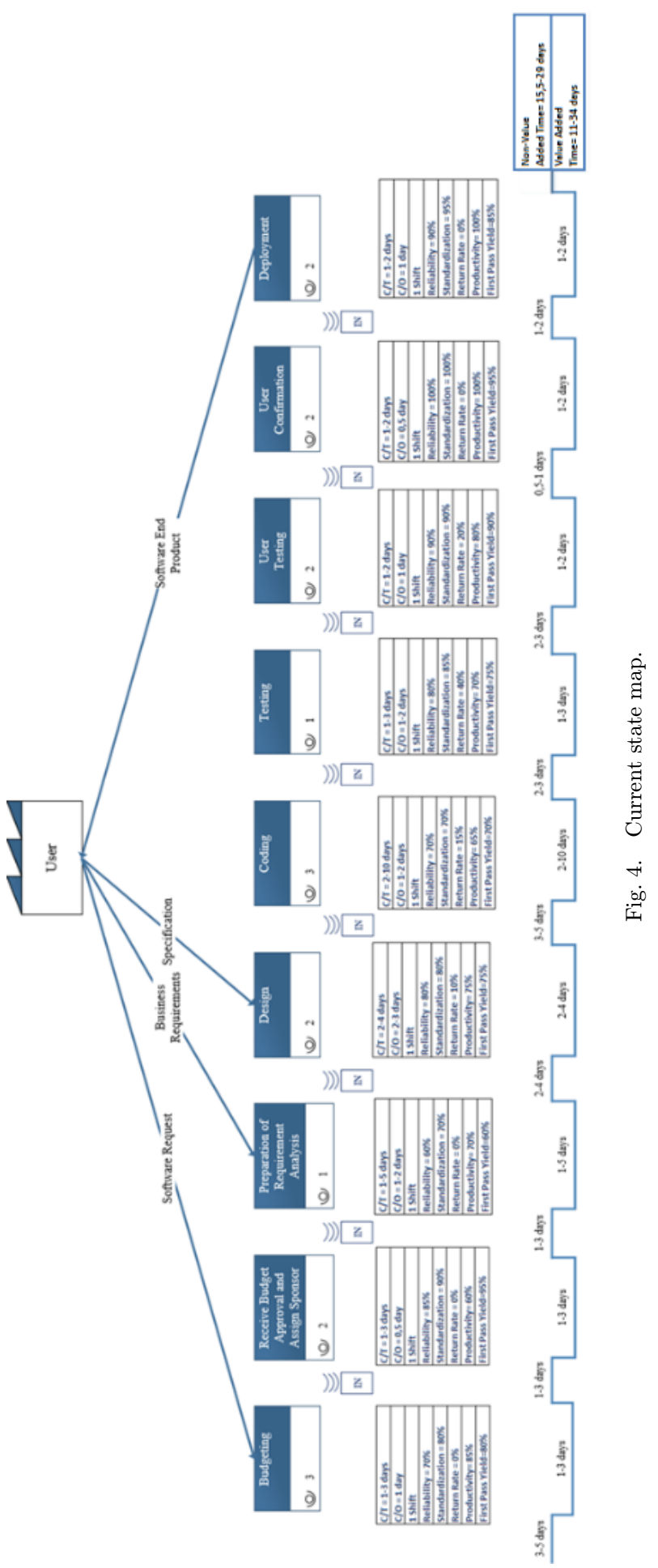


the delay were the following: Longer time was needed to find the documents of the previous projects, requests were misunderstood, budgeting and reporting employee was on vacation. Consequently, budgeting exceeded its allotted period of 1-3 days by days.

The requests that received budget approval were proceeded to the Budget Approval and Sponsor Assignment phase. The prepared budget report was submitted to the top management for approval. The unavailability of top management during the approval period, failure to understand the customer request documents or budget reports, or lack of sufficient detail in these documents caused the approval period to fluctuate between 1 and 3 days. Project management outputs to be produced within the scope of the project were uploaded to the project management tool HP PPM (Hewlett Packard, version: 9.30.0001) and taken into configuration control. Configuration rules for configuration units related to other processes were made in the relevant process definitions. Standard configuration units were created within the scope of requests. For those projects were assigned a sponsor a project plan was prepared by the project manager as in Fig. 5.

At the Requirements Analysis phase, the requirements of the preparation phase were shared among business analysts. In order to elaborate the business requirements, the user was involved at this stage. Requests were completed within 1-5 days.

\begin{tabular}{|c|c|c|c|c|c|c|c|}
\hline & Steps & Delivery & Date & Delivery Responsible & Method & Admissions Officer & Acceptance Criteria \\
\hline 1 & $\begin{array}{l}\text { Determination of Project } \\
\text { Domain }\end{array}$ & $\begin{array}{l}\text { Project Starting Form and } \\
\text { Project Domain Document }\end{array}$ & 1.05 .2016 & Project Manager & Documentation & Sponsor & Approval \\
\hline 2 & $\begin{array}{l}\text { Preparation of Project } \\
\text { Management Plan }\end{array}$ & Project Management Plan & 6.05 .2016 & Project Manager & Documentation & Sponsor & Approval \\
\hline 3 & Demand Detailing & Demand Detail Document & 14.05 .2016 & Business Unit Project Officer & Data & User & $\begin{array}{l}\text { Data in contractual } \\
\text { domain and format }\end{array}$ \\
\hline 4 & $\begin{array}{l}\text { Preparing the server and } \\
\text { database }\end{array}$ & Server and database & 16.05 .2016 & Technical Architect & Data & Project Architecture & Setup \\
\hline 5 & $\begin{array}{l}\text { Requirements Analysis } \\
\text { Document Preparation }\end{array}$ & $\begin{array}{l}\text { Requirement Analysis } \\
\text { Document }\end{array}$ & 31.05 .2016 & \begin{tabular}{|l|} 
Business Analysis \\
Responsible
\end{tabular} & Documentation & $\begin{array}{l}\text { Project Manager, End } \\
\text { User }\end{array}$ & Approval \\
\hline 6 & $\begin{array}{l}\text { Preparation of } \\
\text { Architectural Contract }\end{array}$ & $\begin{array}{l}\text { Architectural Contract } \\
\text { Document }\end{array}$ & 1.06 .2016 & Technical Architect & Documentation & Project Manager & Approval \\
\hline 7 & $\begin{array}{l}\text { Physical Infrastructure } \\
\text { Design Document } \\
\text { Preparation }\end{array}$ & $\begin{array}{l}\text { Physical Infrastructure } \\
\text { Design Document }\end{array}$ & 1.06 .2016 & Technical Architect & Documentation & Project Manager & Approval \\
\hline 8 & $\begin{array}{l}\text { Business Analysis and } \\
\text { Design Review }\end{array}$ & BA ve DR Raporu & 4.06 .2016 & Quality Assurance Officer & E-Mail & Project Manager & $\begin{array}{l}70 \% \text { Overhead } \\
\text { Success }\end{array}$ \\
\hline 9 & Web Service Development & Service & 8.06 .2016 & $\begin{array}{l}\text { Technical Architect, } \\
\text { Software-Solution } \\
\text { Development Specialist }\end{array}$ & Application & Project Manager & Tested \\
\hline 10 & Screen Development & Screen, Flow & 11.06 .2016 & $\begin{array}{l}\text { Software Solution } \\
\text { Development Officer }\end{array}$ & Application & Project Manager & Tested \\
\hline 11 & $\begin{array}{l}\text { Unit Tests and Unit } \\
\text { Integration Tests }\end{array}$ & Unit Test Result Report & 15.06 .2016 & $\begin{array}{l}\text { Project Architect, Solution } \\
\text { Development Supervisor }\end{array}$ & Documentation & Project Manager & Approval \\
\hline 12 & Preparation of Test Script & Test Scripts & 18.06 .2016 & Test Engineer & Documentation & Project Manager & Approval \\
\hline 13 & Preparation of Test Plan & Test Plan & 21.06 .2016 & $\begin{array}{l}\text { Project Manager, Test } \\
\text { Engineer }\end{array}$ & Documentation & Sponsor & Approval \\
\hline 14 & Preparing a Version Plan & $\begin{array}{l}\text { Version Plan \& Operational } \\
\text { Plan }\end{array}$ & 24.06 .2016 & \begin{tabular}{|l|} 
Business Analyst \\
Responsible, Software \\
Solution Development
\end{tabular} & Documentation & Project Manager & Approval \\
\hline 15 & Ready to Test & Test Report & 26.06 .2016 & Quality Assurance Officer & Documentation & Project Manager & $\begin{array}{l}70 \% \text { Overhead } \\
\text { Success }\end{array}$ \\
\hline 16 & $\begin{array}{l}\text { Preparation of Test Result } \\
\text { Report }\end{array}$ & Test Result Report & 27.06 .2016 & Test Engineer & Documentation & Project Manager & Approval \\
\hline 17 & $\begin{array}{l}\text { Acceptance Test Minute } \\
\text { Preparation }\end{array}$ & Acceptance Test & 28.06 .2016 & $\begin{array}{l}\text { Test Engineer, Business } \\
\text { Unit Project Responsible }\end{array}$ & Documentation & Spornsor, User & Approval \\
\hline 18 & User Guide Preparation & Acceptance Test Scripts & 29.06 .2016 & $\begin{array}{l}\text { Test Engineer, Business } \\
\text { Unit Project Responsible }\end{array}$ & Documentation & Sponsor, User & Approval \\
\hline 19 & Productive Readiness & PR Report & 30.06 .2016 & Quality Assurance Officer & E-Mail & Project Manager & $\begin{array}{l}70 \% \text { Overhead } \\
\text { Success }\end{array}$ \\
\hline 20 & Project Closing & Project Closing Report & 30.06 .2016 & Project Manager & Documentation & Sponsor & Approval \\
\hline
\end{tabular}

Fig. 5. A software project plan. 
Inefficient setting of meeting times of user and business analyst and misunderstanding of user demands created a waiting period.

The requests which had the requirements analysis documentation were sent to the design phase and submitted to the Technical Architect. Functions and tasks related to system operation were distributed among hardware personnel, software personnel and users. The technical architect defined the hardware, and special equipment were designed and developed.

The following designs were realized during the software design process:

- Architectural design

- Interface design

- Component design

- Data structure design

- Algorithm design

The processing time can be $2-4$ days depending on the size of the request. The software needs were determined according to the hardware to be used, working environment and database were modeled, libraries and web services were created, the user interface was designed, system relational data structure and system infrastructure relational structure were established. Criteria were set for security, and network controls were provided. Documents related to application technical details were created.

In the Coding phase, the document created by the technical architect was sent to the software programmers, the coding was started according to the technical details, the errors were corrected and the software was created by combining the modules. The developed software elements were integrated with the hardware elements that were produced or bought. The integration process needs to be done with great caution in some large applications where complex hardware structures work together. Unit tests were conducted on the prototypes produced for this stage, the error rates were examined, and software and hardware arrangements were made where necessary. The encoding was done in the Test environment using the Java software language. Completed integrated items were put together and sent to a final testing process in the actual working environment of the system. At the same time, this process included the verification and provision of the system. In the encoding phase, the processing time took $2-10$ days on average depending on the demand size. At this stage, three software engineers were employed. Requests that were $3-5$ days late from design piled up; technical documents were not detailed, so requests were returned and the missing parts were redesigned. Systemic bottlenecks, network problems, or security vulnerabilities caused the waiting periods to increase.

Requests that completed the coding phase were then forwarded to the Testing phase. The Test Engineer created scenarios according to customer demands and loaded them into the HP Application Life Cycle Management (ALM is a web-based tool that supports various phases of the software development life cycle) program used in the firm. These scenarios were run through this program in the test environment, then the mistakes discovered were forwarded to the programmer through the program, and follow-up was provided from this point. Daily reports were 
extracted from this program and sent to the managers for follow-up. System malfunctions, the size of the errors found, and the failure of the network environment caused an interruption in the testing process. 2-3 days waiting periods occurred. After resolving the errors in the tests, the codes for the user test were transferred by the programmer to the UAT environment.

During the User Testing phase, users started testing in the UAT environment. This included training of the person responsible for the use of the system and the elimination of errors that occurred at the end of the first use. Processing times were determined to be 1-2 days. It took half a day to prepare the data to be used in the test. Errors found were also sent via HP ALM to the software programmers. As a test repetition, errors that were resolved were sent first to the tester and then to the user.

After the resolution of the faults and the completion of the tests, to the User Confirmation phase is passed. Defects that cannot eliminated to the due date are taken to the list to be resolved in the next release. The claim processes that complied with the valid criteria were approved by the user.

The codes of the requests that were approved during the Deployment phase were transferred by the software programmers from the UAT environment to the PROD environment, in other words, to real-time environment. A version was created every month. Counter-taking took 1 day but it could take up to 2 days due to systematic troubles or incorrect transmission of codes.

\subsection{Future state design}

After having mapped out the current state of the software management process above, we devised a new model. At this stage, the problems identified in the current state of the firm were solved, and a new process was designed using lean and agile techniques. The design and implementation steps were materialized together within this stage. The current state value stream map was evaluated in terms of processing times and setup times. We found that coding used up the highest processing time. Furthermore, coding and testing processes required the longest setup times. As a result of these analyses, further studies were carried out on coding and test lines to reduce setup time.

According to the Gantt chart prepared by the project team [Çerkezoğlu (2017)], when sufficient completion rate was provided, a project was completed in 33 days. This led to the accumulation of other claims and extra costs. Observations revealed that the demand situation was completed within the range of 11-34 days in the current state map. Criterion ratios were also tracked from the map.

According to the report obtained from the performance measurement program used by the firm, it was necessary to carry out improvement studies related to the criteria in the software development model. Especially the "Preparation of Requirement Analysis" reliability was very low. This indicated either that previous projects were not very carefully examined, and client needs and requirements were not obtained in sufficient detail, or that the drafted documents were too detailed, and in the software phase programmers had not taken the time to read those detailed analyses. 
Errors in planning affected the whole course of the project. These errors stemmed from several reasons: underestimating the complexity of the demand, mispredicting the size of the demand, misattributing the causes of past successes, or bowing to external pressures. Beginning to write software before the analysis was complete prevented the project from reaching the desired quality. In the analysis of earlier similar projects, the reliability rate was determined to be $60 \%$ since the previous plans were used exactly. Generally, the project life cycle was inefficient. There were also delays in the projects and frictions between the units due to the disruptions. In the present project, for example, a software development team accused business units of making unclear requests and constantly changing requests. The additional demands of the business unit led to deviations from the project. There were also complaints because the software development team was exposed to constant pressure from the project management unit. On the other hand, the business unit in turn accused the software development team for its slow pace. The lack of communication between daily living units increased inefficiency.

The distances in the office environment also negatively affected the project process. The distance between the business unit and the software development unit was one of the factors that increased miscommunication. Business unit was on the 1st floor while the software development team was on the sixth floor, and the project management unit was on the fourth floor in the company. This situation resulted in delays or absences in meeting attendance. In another case, the need for documentation was increasing as the planning, budgeting and analysis phases were based on previous projects. The complexity of the documents in the closets made it difficult to find the required documents. Files spilling out of cabinets piled on tables, creating an ugly image. Also, the fact that there was no common space on the computer caused a lot of time waste. In order to remedy this situation, application of $5 S$ was started ( $5 \mathrm{~S}$ is a technique that originated from Japan, and it includes five words: Seiri, Seiton, Seiso, Seiketsu, and Shitsuke, which means Sort, Set in order, Shine, Standardize, and Sustain, respectively [Vipulkumar and Thakkar (2014); Jackson (2009)]. As part of this project, during the Seiri phase necessary and unnecessary objects were sorted. Unnecessary objects were identified with red tags and moved to red areas. The files were placed in an orderly fashion and numbered in cabinets. Finally, this change was standardized and made routine.

The level of education of project employees was also an important factor in the process. Software development units should be graduated from computer, mathematics or software engineering, business units from economic and administrative sciences, and project management unit from business or industrial engineering departments. The professional background of project team members was as follows:

- Software Engineers had degrees in Computer Engineering,

- Business Unit members had degrees in Business Administration,

- Project Manager was an Industrial Engineer.

As can be seen, the team members had the necessary professional qualifications. 
As the number of delays increased, the solution path began to be searched. Because Agile transformation software methodologies [Singh et al. (2015); Başar et al. (2014); Boehm and Turner (2003)] support Lean principles [Hines and Taylor (2000); Keyte and Locher (2016); Womack and Jones (2010); Byrne (2015)], we decided to test one of those Agile methods, the SCRUM (proposed as an alternative to Waterfall, SCRUM is a process framework used to manage the complex product development process) [Yitmen (2015); Sutherland and Schwaber (2016); Deemer et al. (2012)].

When the agile conversion was be used for the first time, SCRUM training was given to the IT department by a specialist company. This project was also identified as a pilot project. The SCRUM Team that was created for the project was as follows:

- SCRUM Master: One employee,

- Product Owner: One Employee,

- SCRUM Development Team: Five Employees

The project process progressed by applying the following SCRUM steps:

- The Product Owner prepared a Product Backlog prioritizing all the functions that needed to be developed.

- Once the team was identified, it started working using "Sprint Planning," made up of small cycles of up to four weeks called "Sprints". A "Sprint Backlog" was created for each cycle and was developed throughout the sprint.

- During this "Sprint", the team came together daily under the leadership of Scrum Master (Daily Scrum Meeting), and each team member explained his or her own progress within a maximum of $15 \mathrm{~min}$. The remaining requirements and elapsed time graph during the sprint were updated.

- When Sprint was over, a "Sprint review" report was issued, and the problems that arose during the sprint were removed so that the next sprint started more comfortably.

- Each piece completed at the end of the Sprint was shown to the user.

The work to be done was divided into small threads and specified in SCRUM board. While working in this way, the team created alternative solutions by sharing constructive ideas among themselves. In this project, the regression was automated to save time.

SCRUM manifestos of Agile software methodologies were adopted in order to shorten the time required to meet requests for the formation of the Future State Map (Fig. 6). Errors were reduced using lean techniques and improvements were made. Defining short-term milestones or checkpoints allowed comparison of constructions with short intervals of the plan, preventing deviations from the plan.

When the Future State Map was analyzed, it was seen that the budget and software development stages were being cellularized. The "budgeting and approval process" was cellularized so that the waiting period of $1-3$ days seen in the Current State Map appeared to be out of the question. In addition, the Requirements Analysis, Designing, Coding, Testing and User Testing stages were also cellularized 


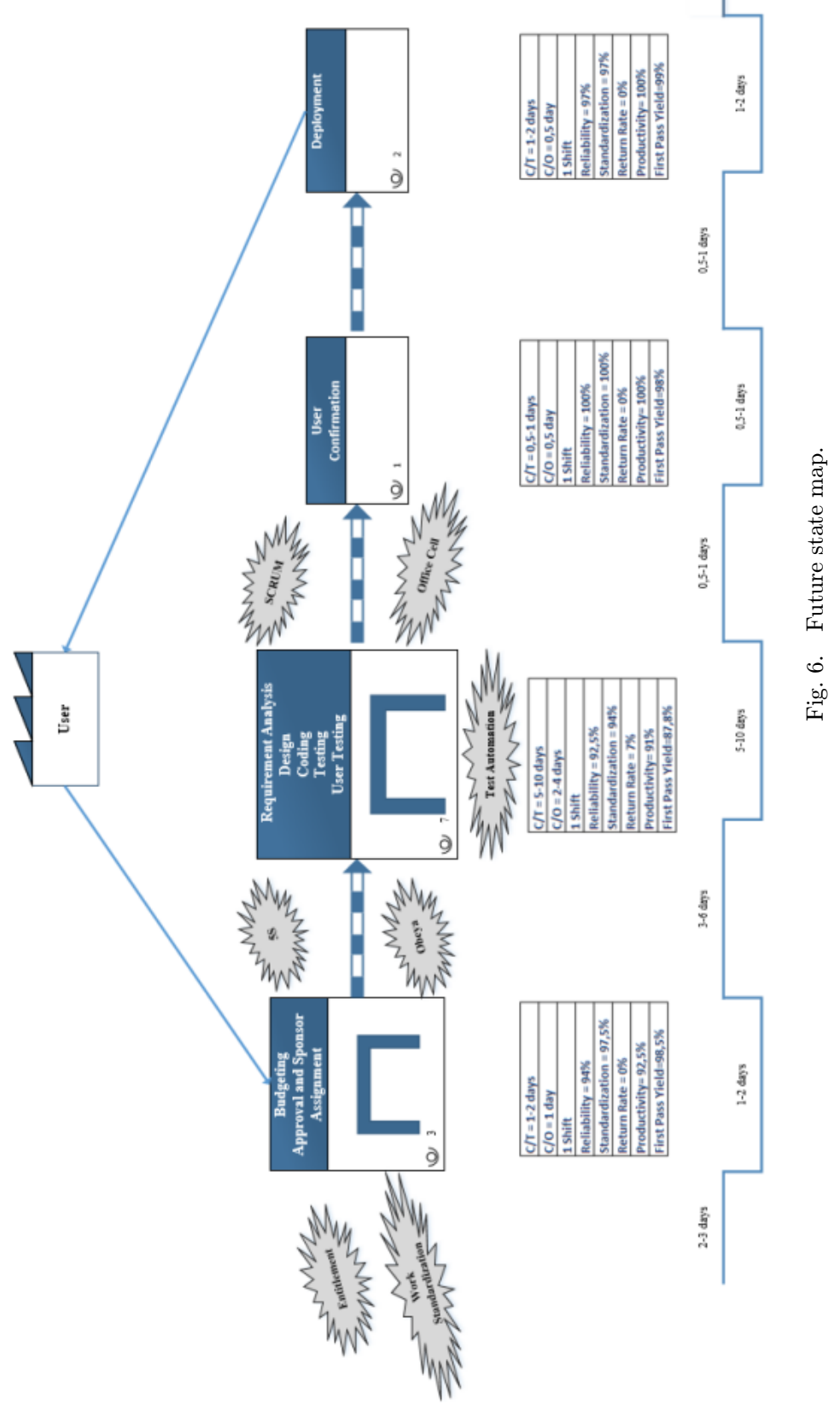


and the waiting period 9-15 was also reset. A supermarket system [Rother and Shook (1999)] was decided between the two cells, and the waiting period was reduced to $6-11$ days.

When the agreed completion rates were met according to the Gantt chart [Tanrikut and Çerkezoğlu (2017)], the project was completed in 16 days in the first application. Lean philosophy was adopted within the cells, especially in the software development cell, and the following targets were set:

- Waste reduction: The most important principle of the system was accepted: Customer demands were to be given top priority. During the software development phase, non-mandatory requirements that were not demanded by the client were removed from the procedure.

- Optimizing the whole system: This principle recommended that software developers consider, investigate and understand the system as a whole. The software development team aimed not only to improve the test phase, but also to improve the entire SDP.

- Quality improvement: The revision activities used at different stages of software development were now being made according to quality standards. The Test Guided Development and Co-Programming techniques for agile development began to be used.

- Continuous learning: Continuous development of the technology necessitates the software development team members to keep themselves constantly up-to-date and open to learning.

- Rapid delivery: The software development team aimed to develop products quickly and deliver fast delivery to customers.

- Team empowerment: Software developers in the team were encouraged to trust, respect and help each other.

- Timely decision-making: The team was urged to take adequate time for decisionmaking, following opinion exchanges, because hasty decisions were observed to lead to more mistakes.

\subsection{Design and implementation of the work plan}

In the project management which is the main idea of the work, the VSM is used for process improvement. SCRUM and Lean Techniques were adopted from the agile software development models and improvements were made on the project. Figure 7 describes the areas, times, and responsible managers that need improvement. Although the work plan was set on an annual timetable for the manufacturing sector, for an information company it was prepared as monthly because the demand for the information was monthly from the user and needed to be solved within one month.

Lean methods were used to reduce the lead time. A suitable working environment was provided with the $5 \mathrm{~S}$ method in the office, and method study for time and training was also used. In the current daily working hours $(8 \mathrm{~h}), 1 \mathrm{~h}$ of job loss would affect the project process, so time loss was reduced to the minimum with method study. Time waste resulted from carelessness, late arrival or early departure, slow 


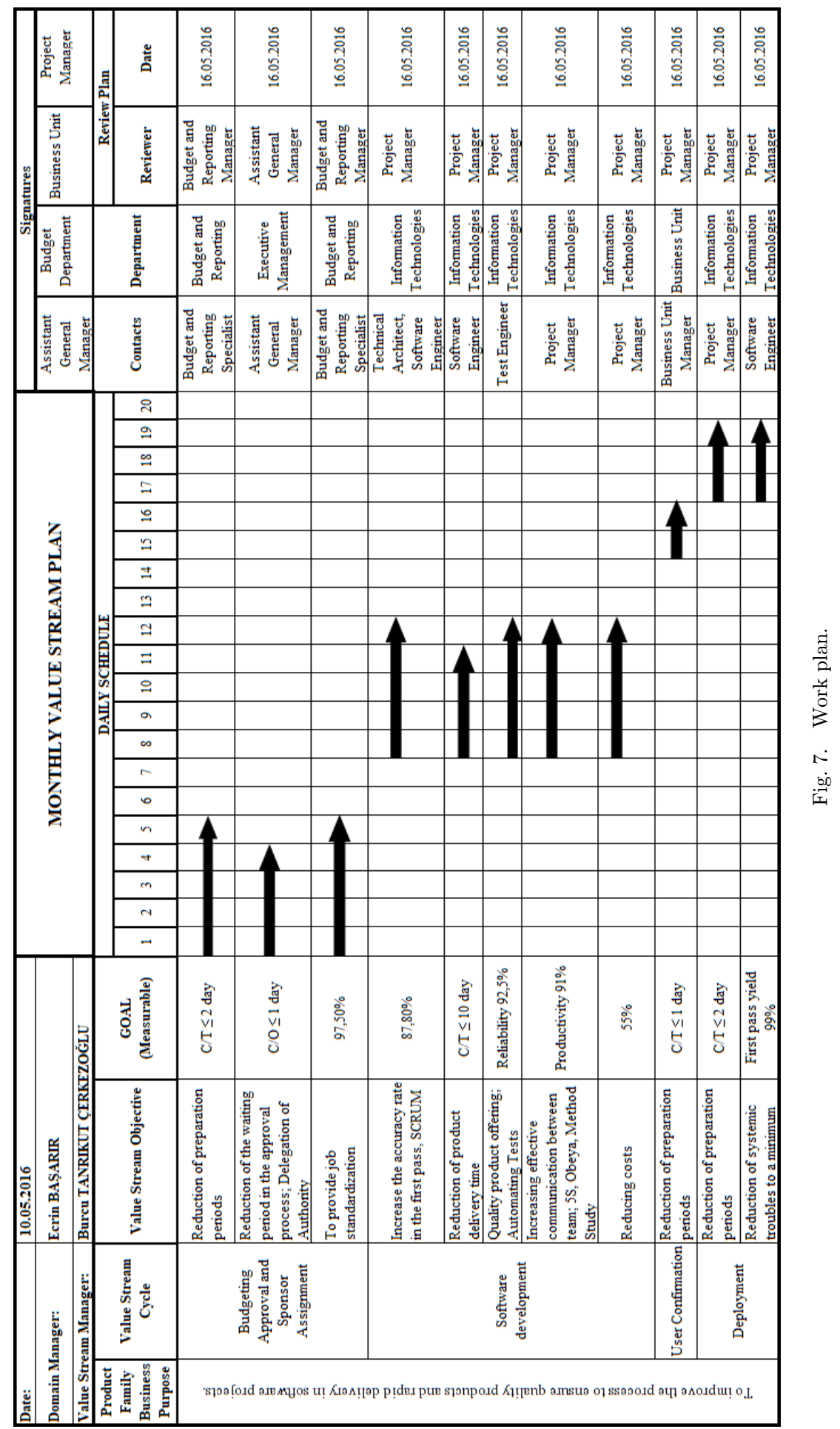


pace, or distractions at work. For example, too many pauses taken by software developers were observed to interrupt the process and increase the rate of code writing errors. For this reason, the lead time up to test that was supposed to have been three days went up to 5-6 days. Further errors are caused from work overload on the test team, which prevents the test engineer from focusing on any single task and consequently results in omission of errors.

Method study yielded the following results:

- Increase in employee working speed,

- Improved working conditions,

- Fair workload distribution,

- Efficient working conditions,

- Elimination of unnecessary employee movements.

We recommended that the company follow the method study, which is very systematic. First, job choice was made. Incoming requests were ordered by priority. Planning for these ordered requests was made and recorded. Workload was distributed evenly to team members. A large meeting room was set up for work. This enabled effective communication within the team and eliminated unnecessary movements. Standardization was provided to ensure continuity.

In the company the layout of offices spread far out from one another reduced efficiency, from a lean perspective. As a solution, for project follow-up and evaluation the cellularized software development team began using the OBEYA Room [Javadi et al. (2013); Wastradowski (2017)]. The objective of using the communicationfacilitating OBEYA Big Room system was to bring into prominence simultaneous sharing of employee opinions and assessments on all issues. Placement of the team in one room enabled the team to focus on processes. When in the same room employees specializing in different areas tended to constantly learn from one another. All project data, drawings and graphics were affixed to the walls in the room. Lean and Agile Project Management recommends that teams work together in a single room or around the same table. Thanks to implementation of the OBEYA technique, delivery was accelerated, work quality improved, project cost decreased, mutual learning was facilitated, and continuous improvement was realized.

Excessive numbers of employees also increased miscommunication in the team. While the waterfall model was applied, 18 employees were working, and with the adoption of the SCRUM model the number of employees was reduced to 10. Seven of these 10 were members of the software development team, while the remaining three were cellularized as the budgeting and approval team. Thus, communication within the team was strengthened and misunderstandings were eliminated. SCRUM helped enhance transparency, strengthened team communication, enabled adaptation to the rapid changes in requirements, and thus contributed to solving problems up to project delivery.

The implementation of VSM in the SBT firm showed that the value added in the present case was 11-34 days. By designing the future case, this time is expected to decrease to $7.5-15$ days, thereby resulting in $45.7 \%$ time savings. It is noteworthy 
Table 4. Ratios between current and future situation criteria.

\begin{tabular}{|c|c|c|c|c|c|c|c|c|c|}
\hline & Budgeting & $\begin{array}{l}\text { Receive } \\
\text { budget } \\
\text { approval } \\
\text { and assign } \\
\text { sponsor }\end{array}$ & $\begin{array}{l}\text { Preparation } \\
\text { of } \\
\text { requirement } \\
\text { analysis }\end{array}$ & Design & Coding & Testing & $\begin{array}{l}\text { User } \\
\text { testing }\end{array}$ & $\begin{array}{c}\text { User } \\
\text { confirmation }\end{array}$ & Deployment \\
\hline Reliability & $20 \%$ & $13 \%$ & $27 \%$ & $15 \%$ & $20 \%$ & $15 \%$ & $5 \%$ & $0 \%$ & $7 \%$ \\
\hline Standardization & $15 \%$ & $10 \%$ & $25 \%$ & $15 \%$ & $16 \%$ & $9 \%$ & $5 \%$ & $0 \%$ & $2 \%$ \\
\hline Return Rate & $0 \%$ & $0 \%$ & $0 \%$ & $-8 \%$ & $-7 \%$ & $-20 \%$ & $-15 \%$ & $0 \%$ & $0 \%$ \\
\hline $\begin{array}{l}\text { Efficiency } \\
\text { (Working } \\
\text { Time) }\end{array}$ & $10 \%$ & $30 \%$ & $25 \%$ & $15 \%$ & $20 \%$ & $20 \%$ & $15 \%$ & $0 \%$ & $0 \%$ \\
\hline $\begin{array}{c}\text { First Pass } \\
\text { Yield }\end{array}$ & $17 \%$ & $5 \%$ & $25 \%$ & $15 \%$ & $15 \%$ & $12 \%$ & $2 \%$ & $3 \%$ & $14 \%$ \\
\hline
\end{tabular}

that while in a manufacturing process non-value added time is greater than valueadded time, in software development the opposite was observed to be the case. The lost time in manufacturing may depend on machine and method whereas in software development it may be the impact of brainpower and human behavior that leads to time waste.

Reliability, Standardization, Return Rate, Productivity and First Pass Yield showed a high rate of improvement. In a short period of time, user satisfaction was achieved with product developments presented to the user. The user was present at every stage of the project because of the agile model, and there was no difficulty in understanding the requests. With the use of cellular staffing and flexible workforce, workload distribution was made more smoothly, and product delivery was speeded up.

As may be seen in Table 4, the greatest increase in efficiency was achieved in the "Budget Approval Acquisition and Sponsor Assignment" phase (30\%). This efficiency increase was achieved by establishing work standardization and by making improvements in the delegation of authority. Previously, projects were approved by certain names, and if they were on annual leave, the requesting approvals would be kept waiting until these managers returned. Now, when those managers are on leave, approval delay is prevented by making sure that authority is delegated to other managers. Where business approval procedures were not previously documented in detail, with the recommended model, the budget documentation approval procedures were documented in more detail in the approval process.

Another important increase is that while the Requirement Analysis Preparation reliability rate was $60 \%$ when the Waterfall method was applied, this ratio increased to $87 \%$ with the new method, thus a $27 \%$ increase was achieved. This increase was accomplished as a result of having the user present at every stage of the process.

A significant decrease in error return rates was also observed. Since the work was sliced up into smaller pieces, and testing was accomplished after delivery of each piece, immediate intervention was possible when problems occurred, and this accelerated the project process. Since the OBEYA method was used throughout the process - in analysis, design, coding, and testing - continuous flow in the cell was achieved. Every employee in the SCRUM team could do the work of another; unlike 
the waterfall model, in the SCRUM model team members do not have definite roles. Team members act not as individuals but as a team, and adopt a sharing attitude is being followed. Furthermore, the SCRUM method thereby results in the elimination of the waiting times of the waterfall model. Cellular work was also effective in reducing waiting times. While the waiting time between processes was 15.5-29 days, the waiting time in the new model decreased to 6-11 days. Thus, the demand accumulation was eliminated.

As a result of lean techniques and work study practices, the rate of productive working time was also observed to increase. Previously, locating required documents took time. With the OBEYA method, the team working in the large meeting room does not place any items on the table except for work, each document has its place and can easily be located, saving time.

\section{Conclusion}

In this paper, the problems experienced in the SDP are researched and a model is presented to create innovation in the process so that the process can be improved by eliminating these problems. In addition to the problems mentioned in the literature, basic problems and the factors that cause these problems have been determined in detail by examining a real SDP. These factors, which can lead to work accumulation, delays, quality problems, inefficiency and spiralling costs, and which are likely to occur in all software companies, can be classified in Table 5.

The lean and agile approaches that were applied to solve the identified problems in the SBT company were successful. Consequently, this model is proposed to meet an important managerial need. Customer involvement throughout the process of

Table 5. Possible problems in SDP.

\begin{tabular}{ll}
\hline Management based & - items that are not assessed or escaped during the contract phase \\
- lack of understanding \\
- authorization not allowed \\
- inefficient adjustment of meeting times for user and business analyst \\
- constant pressure to get results \\
- unable to establish effective communication between units \\
- incorrect transmission of codes \\
- demand simple vision, inability to predict size \\
- miscalculation of previous successess \\
- education levels and job suitability \\
- carelessness \\
- late coming to work or early exit \\
- too much break \\
- take care of other things at work \\
- write incorrect code \\
- slow operation \\
- cannot focus on one job with the accumulation of jobs \\
- start writing software before the analysis is complete \\
- less communication with the customer \\
\end{tabular}


Table 5. (Continued)

\begin{tabular}{|c|c|}
\hline System based & $\begin{array}{l}\text { - system faults, size of faults found, } \\
\text { - network environment does not work, } \\
\text { - security vulnerabilities }\end{array}$ \\
\hline Documentation based & $\begin{array}{l}\text { - incomprehensible } \\
\text { - inadequate or incomplete detail } \\
\text { - excessive detail } \\
\text { - numerous and complex }\end{array}$ \\
\hline Method based & $\begin{array}{l}\text { - long preparation times } \\
\text { - accumulation of works } \\
\text { - unnecessary movements } \\
\text { - waste of time in finding documents of previous projects }\end{array}$ \\
\hline $\begin{array}{l}\text { Layout based } \\
\text { Customer based }\end{array}$ & $\begin{array}{l}\text { - remote office environments } \\
\text { - unclear requests } \\
\text { - change your mind often } \\
\text { - proposing different demands }\end{array}$ \\
\hline
\end{tabular}

software development, top management support, and clear requirements are the major managerial implications of this study. It is also worth noting that the importance of these factors in the success of software development projects also has the support of a Standish Group report [Hastie (2015)].

It is foreseen that the analysis of the current situation in the model in Fig. 8 should be carried out with a lean perspective, then in the course of designing the changes, especially lean and agile approaches and industrial engineering techniques should be implemented. The main methods and techniques applied in this case are the following: SCRUM; OBEYA, VSM, 5S, Cellular Layout, Continuous Flow, Short Prep Time, Work Standardization, Automation, Delegation of Authority, Time and Method Study, Continuous Learning, Team Spirit, Cross Training and Multifunction Personnel Employment, Accurate Personnel and Job Assignment, Personnel Training, Close Relationship with Customer/User.

Here, the current situation is analyzed with VSM, and the process was improved with lean and agile techniques. Thanks to the synergy created by the OBEYA, SCRUM, cellular office, method study, and personnel training, all of the planned activities were implemented and the following savings were achieved:

With method study, training and 5S, more effective working conditions and business environment were created, and equitable workload allocation was achieved. As a result of these applications, a significant decrease was realized in unnecessary movements and lost time, providing standardization. Furthermore, the number of staff required for the same job decreased.

With the application of cellular offices and flexible workforce, waiting times were reduced and team work was established.

With OBEYA, software developers could focus on one job at a time, resulting in faster exchange of ideas, mutual learning and continuous improvement in process. As a result, job quality was increased, delivery was accelerated, and cost was decreased.

With SCRUM application, misunderstandings were eliminated thanks to strong communication and transparency, the customer was involved in every stage of the project, fulfillment and delivery of the requested changes were speeded up. 


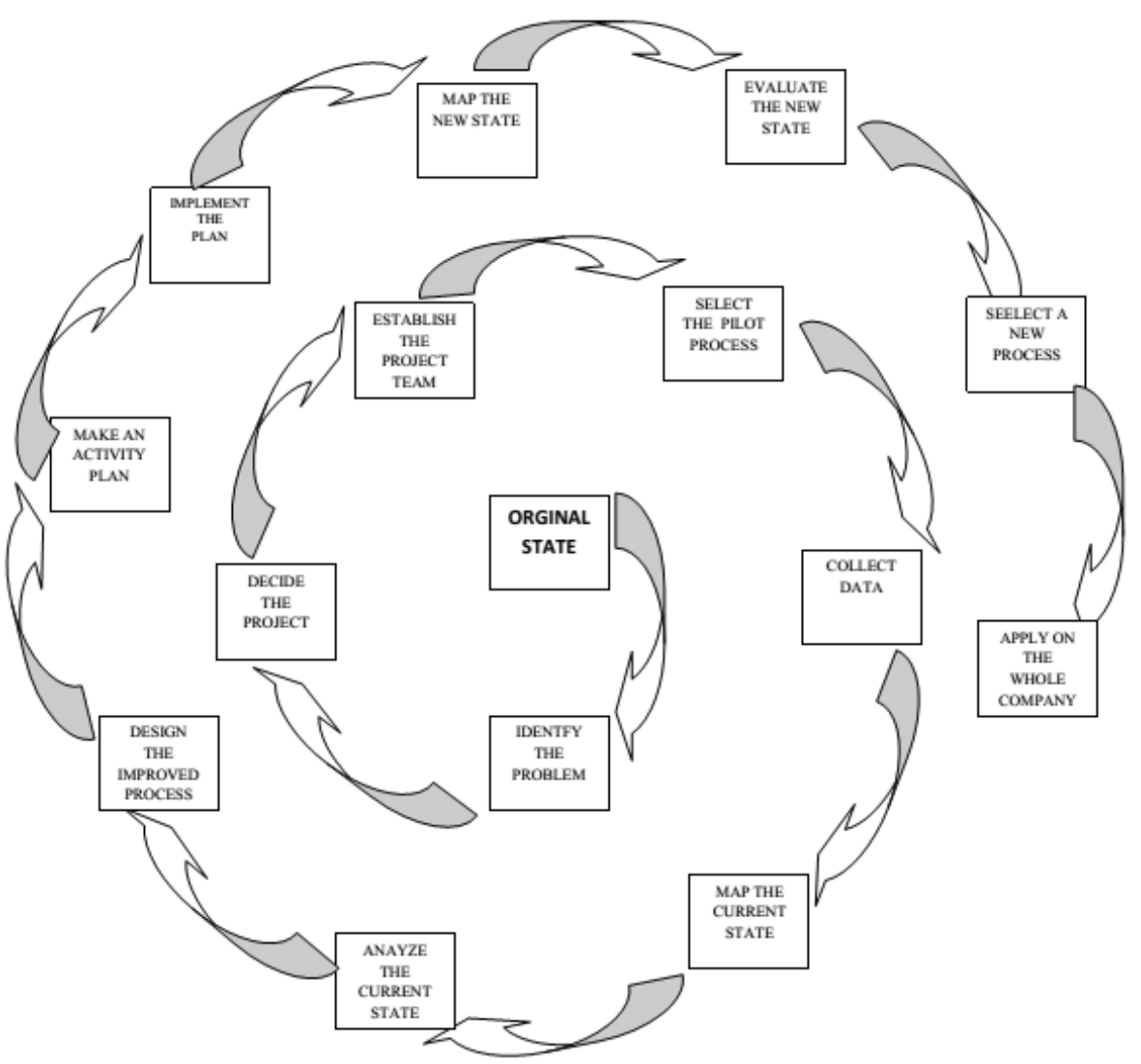

Fig. 8. Model developed for SDP improvement.

As a result of the above applications enabling quick thinking, rapid decisionmaking, rapid development and control, the time spent on value-adding activities was reduced by about half when performing the same project.

Consequently, when the applications proposed in the design step were implemented, reliability improved, standardization was achieved, return rate, efficiency, and the first yield pass indicators were greatly improved. The customer's satisfaction increased because the user was involved in the development of the production. Naturally this resulted in an increase in the project capacity of the company. Consequently, the proposed model is expected to put companies in a better position to increase their market share. At the same time, it may offer companies the opportunity to adapt to Industry 4.0 with speed, flexibility and quality.

Described in this study is an innovative pilot project which resulted in significant process and product improvements. According to the developed model, the cycle requires the application to be extended to the whole system. It is important that new pilot projects be selected from the different business units to be implemented so that the application of the model within the firm can spread rapidly. As important achievements are made in this regard, the success of the first pilot project will prove to be no coincidence, and user satisfaction will increase. 
Agile methods need to be implemented not only within the scope of information processing or software projects, but they should be also prevailing in the administrative infrastructure of the entire company. Lean philosophy should be adopted not only on the basis of project management but also in every process of the company. The managers need to be conscious and encourage their employees to implement their practices in lean thinking. Employees must continue to work with the awareness of the necessity of lean thinking for achieving bigger goals, sustainability and competitive advantage.

It has been observed that decision-making mechanisms are accelerating as the management stages of the Software Development team decrease. If this is done in other departments, it is predicted that saving time and cost will be achieved by reaching a quick result.

5S and Method Study techniques should also be adopted not only in the software development team but also in the entire firm. There is a big role for the managers here. First, managers need to educate and offer guidance to employees. Training about these techniques should be given. Techniques related to slogans, posters and bulletins can be arranged, and employees can be attracted. Competition for making proposals/ideas can be made on the improvement level, the days of the techniques can be organized (such as the $5 \mathrm{~S}$ day), the participation of all employees can be ensured or the employees can be challenged by making the best department competition.

In the same way, the OBEYA technique can also be adopted in most departments of the company. Building OBEYA rooms will allow the company to dedicate separate, stand-alone areas to each project, and in that way enable monthly and quarterly plans to be made in those areas. By using this technique, time loss may be prevented to a great extent, employee morale and motivation can be improved in a clean and organized environment, and process quality may be improved by arrangement and layout.

In this application, which is realized in the software sector, where the lack of user participation is the biggest share of failure, the customer was included in every phase, and misunderstanding was prevented. Consequently, the software was produced at the right time and in the desired accuracy. As a result of the implementation, a faster, more agile and efficient process was achieved and customer satisfaction increased. These results suggest that software developers can gain a competitive advantage and at the same time comply with the requirements of the Industry 4.0 age by using agile and lean processes.

Industry 4.0 is a development that emerging or underdeveloped countries must adopt. As the mainstay of Industry 4.0, the software industry is especially well placed to propel emerging markets forward.

The software industry offers emerging countries the chance to catch up with developed countries in Industry 4.0. By capitalizing on their educated and qualified workforce or by investing in the training of that workforce, they may develop their software industry to a level of global competitiveness. The model and the steps presented here is offered as a guide that software companies can use to achieve that level of global competitiveness. 
Future research can use Axiomatic Design principles to explain the model presented here in greater detail.

\section{Acknowledgment}

The authors are grateful to Guest Associate Editor and Associate Proffessor Dr. Tanses Y. Gülsoy who has given every effort and support to all of this paper in order that it complies with the rules of writing and is clear and understandable.

\section{References}

Abe, S., Mizuno, O., Kikuno, T., Kikuchi, N. and Hirayama, M. (2006). Estimation of project success using Bayesian classifier. In Proceeding of the 28th International Conference on Software Engineering, ICSE'06, Shanghai China, pp. 600-603.

Acar, Ö. (2008). What is the extreme programming? In Turkish: Extreme Programming Nedir. Available at http://www.kurumsaljava.com/2008/11/21/extreme-programmingnedir/ [accessed on 8 February 2017].

Aktan, C. C. (2008). Strategic management and strategic planning (in English): Stratejik Yönetim ve Stratejik Planlama), Çimento İşveren, pp. 4-21.

Başar, A., Özkaya, A. and Kesgin, F. (2014). Agile approach transition from waterfall method in software development process: Application in a techology firm (in Turkish: Yazılım Geliştirme Süreçlerinde Şelale Yönteminden Çevik Yaklaşıma Geçiş: Bir Teknoloji Sirketinde Uygulama), Ziraat Teknoloji A.Ş., İstanbul, pp. 225-226.

Birgün, S., Gülen, K. G. and Özkan, K. (2006a). Using the value stream mapping technique in lean production transition process: An application in manufacturing sector (in Turkish: Yalın Üretime Geçiş Sürecinde Dĕger Akışı Haritalama Tekniğinin Kullanılması: İmalat Sektöründe Bir Uygulama), İstanbul Ticaret Üniversitesi Fen Bilimleri Dergisi, 5, 9: 47-59.

Birgün, S., Gülen, K. G. and Özkan, K. (2006b). A case study on eliminating waste from the business processes. In Proceedings of the 15th Annual World Business Congress, International Management Development Association, Sarajevo, Bosnia and Herzegovina, pp. 41-46.

Birgün, S. and Çerkezoğlu, B. T. (2017). A software development process improvement study to support compatibility with Industry 4.0 for software maker. In Proceedings of the International Symposium for Production Research 2017, Vienna, 13-15 September 2017, pp. 91-100.

Boehm, B. W. and Turner, R. (2003). Balancing Agility and Discipline: A Guide for the Perplexed. Addison-Wesley Longman Publishing Co., Inc. Boston, MA, USA, pp. 35-54.

Byrne, A. (2015). Yalın Dönüşüm (in English: Lean Transformation), Melis İnan (trans.), İstanbul: Optimist, p. 109.

Çandur, C. (2010). Banking IT project management and MS project planning (in Turkish: Bankacılık IT Proje Yönetimi ve Ms Project'le Proje Planlama), Master Thesis, Haliç University, pp. 72-76.

Çerkezoğlu, B. T. (2017). Improvement of the project management process: An application in software industry (in Turkish: Proje Yönetim Sürecinin İyilestirilmesi: Bilişim Sektöründe Bir Uygulama), Master Thesis, Beykent University, İstanbul, pp. 80-94.

Çetin, E. and Durdu, P. (2015). A study on agile software development in Turkey (in Turkish: Türkiye'de Çevik Yazılım Geliştirme Üzerine Bir İnceleme), Master Thesis, Kocaeli University, pp. 15-17.

Deemer, P., Benefield, G., Larman, C. and B. Vodde (2012). A lightweight guide to the theory and practice of SCRUM (version 2.0). Technical report. Available at http://www. scrumprimer.org. 
Gül, Z. (2006). Improvement of software development process and Turkey applications (in Turkish: Yazılım Geliştirme Sürecinin İyileştirilmesi ve Türkiye Uygulamaları), Master Thesis, İstanbul Technical University, pp. 19-25.

Güven, Ş. (2015). Lean new venture from entrepreneurship methodologies, and exemplary application in the information sector (in Turkish: Girişimcilik metodolojilerinden yalın yeni girişim ve bilişim sektöründeki örnek uygulamasi), Master Thesis, Bahçeşehir University, Istanbul, pp. 17-18.

Hastie, S. (2015). Standish Group Chaos Report. Available at www.infoq.com/articles [accessed on 2017].

Hermann, M., Pentek, T. and Otto, B. (2015). Design principles for Industrie 4.0. scenerious: A literature review. Working Paper No.01/2015, Technische Universität Dortmund

Hines, P. and Taylor, D. (2000). Going Lean - A Guide to Implementation. Cardiff Business School, Lean Enterprise Research Centre, United Kingdom, p. 10.

Jackson, T. (2009). 5S for Healthcare (Lean Tools for Healthcare Series). Productivity Press, Taylor ve Francis Group, New York.

Javadi, S., Shahbazi, S. and Jackson, M. (2013). Supporting production system development through the Obeya concept, Christos Emmanouilidis; Marco Taisch; Dimitris Kiritsis. In 19th Advances in Production Management Systems (APMS), September 2012, Rhodes, Greece, Springer (IFIP Advances in Information and Communication Technology, AICT397 (Part I)), pp. 653-660.

Kaur, R. and Sengupta, J. (2011). Software process models and analysis on failure of software development projects. International Journal of Scientific and Engineering Research, 2, 2: $1-4$.

Keyte, B. and Locher, D. A. (2016). The Complete Lean Enterprise: Value Stream Mapping for Office and Services. CRC Press, Taylor and Francis, New York.

Nalbant, S. (2012). Increasing the efficiency of the software development process: An information system advice (in Turkish: Yazılım Geliştirme Sürecinin Verimliliğini Arttırmak: Bir Bilgi Sistemi Önerisi), Master Thesis, Middle East Technical University.

Neumann, S., Probst, C. and Wernsmann, C. (2003). Continuous process management. Process Management: A Guide for the Design of Business, Springer, Berlin, pp. 233-251.

Nizam, A. (2015). Software project management. In Turkish: Yazılım Proje Yönetimi, 2. Basım, İstanbul, Papatya, p. 33.

Palmer, S. R. and Felsing, M. (2001). A Practical Guide to Feature-Driven Development, Pearson Education, USA, pp. 57-63.

Rother, M. and Shook, J. (1999). Learning to See, Version 1.2. The Lean Enterprise Institute Inc, Brookline, Massachusetts, USA.

Seth, D. and Gupta, V. (2005). Application of value stream mapping for lean operations and cycle time reduction: An Indian case study. Production Planning $\&$ Control, 16, 1: $44-59$.

Singh, D., Thakur, A. and Chaudhary, A. (2015). A comparative study between waterfall and incremental software development life cycle model. Journal of Emerging Trends in Science and Technology, 2, 4: 2204-2208

Sutherland, J. and Schwaber, K. (2016). SCRUM Guides. Available at: www.scrumguides. org/docs/ [accessed on 2017].

Svensson, R. (2006). Successful software projects and products, Master Thesis, Software Engineering, Blekinge Institute of Technology, pp. 9-14.

Tapping, D., Luyster, T. and Shuker, T. (2002). Value Stream Management Eight Steps to Planning, Mapping and Sustainining Lean Improvements. Productivity Inc., New York, USA.

TUSIAD (2016). Turkey's global competitiveness as a necessity for Industry 4.0: Emerging economy perspective executive summary (in Turkish: TUSIAD, Türkiye'nin Küresel Rekabetçiliği için Bir Gereklilik Olarak Sanayi 4.0: Gelişmekte Olan Ekonomi Perspektifi Yönetici Özeti), No. TÜSİAD-T/2016-03/576. 
Vipulkumar, C. P. and Thakkar, H. (2014). Review on implementation of 5S in various organization. International Journal of Engineering Research and Applications, 4, 3: 774-779.

Wastradowski, M. (11.8.2017). OBEYA in the workplace: An overview. Available at: https:// www.graphicproducts.com/articles/obeya-in-the-workplace-an-overview/.

Womack, J. P. and Jones, D. T. (2003). Lean Thinking: Banish Waste and Create Wealth in Your Corporation. Simon and Schuster, New York.

Womack, J. P. and Jones, D. T. (2010). Lean thinking (in Turkish: Yalın Düşünce), Oygur Yamak (trans.), İstanbul: Optimist, pp. 23-433. Available at: www.infoq.com/articles/ Standish-chaos-2015 [accessed on 29 September 2017].

Yitmen, M. (2015). SCRUM a transformation story agile project management (in Turkish: SCRUM Bir Dönüşüm Hikayesi Agile Proje Yönetimi), Seçkin, İstanbul, p. 21.

\section{Biography}

Semra Birgün is full professor and chairperson of the Industrial and System Engineering Department of Fenerbahçe University in Istanbul, Turkey (HYPERLINK "mailto:semra.birgun@fb.edu.tr" \t “_blank” semra.birgun@fb.edu.tr). She holds a B.S. degree in mechanical engineering from Y1ldı Technical University (Istanbul, Turkey) and M.S. and Ph.D. degrees in management engineering from Istanbul Technical University. Her research areas are lean production, design and analysis of manufacturing systems, and production planning and control, and she has numerous publications in those areas.

Burcu Tanrıkut Çerkezoğlu is a systems analyst at the insurance company Halk Hayat ve Emeklilik in Istanbul, Turkey. She holds a double major diploma in business administration and mathematics and computer science from Istanbul Kultur University (Istanbul, Turkey) and an M.S. in industrial engineering from Beykent University (Istanbul; Turkey). Her research areas are project management, software development, and agility and management in information systems. 